\title{
Analysis of Variety of Learning Difficulties to Indonesian Language Education Students on English Language Courses at University of Ma'arif Nu Kebumen
}

\author{
Alek Andika, Endah Mitsalina \\ Universitas Ma'arif Nahdlatul Ulama Kebumen \\ mralek_andika@yahoo.com
}

Article History

accepted 24/09/2019

approved 01/10/2019

published 01/12/2019

\begin{abstract}
Mastery of English as an international language is a necessity at this time. Indonesia as a member of the AEC (ASEAN Economic Community) should properly prepare for this challenge by preparing a capable and skilled generation of the nation. English is an international language that is very important for communication and connecting people with the world in various aspects including education. The government shows its seriousness in improving English language skills to the nation's generation, namely by requiring English at the educational level. In reality, there are various difficulties faced by students when learning English, especially in learners / students who are not from the English department called ESP (English for Specific Purposes) Learners. This study aims to dig deeper into the variety of difficulties faced by students in learning English in students of Indonesian Language Education Study Program at FKIP Ma'arif University NU Kebumen. This study uses a qualitative approach with questionnaire instruments, observation and indepth interview. Analysis of research data was carried out through three stages, namely data reduction, data presentation and conclusion drawing. The results of this study indicate that research subjects face a variety of difficulties learning English, namely: 1) lack of student confidence, 2) students rarely use English in daily life and, 3) lack of vocabulary mastery.
\end{abstract}

Keywords: various difficulties, learning, English

\begin{abstract}
Abstrak
Penguasaan bahasa Inggris sebagai bahasa internasional merupakan sebuah keniscayaan pada saat ini. Indonesia sebagai salah satu anggota MEA (Masyarakat Ekonomi ASEAN) sudah sepatutnya mempersiapkan tantangan ini dengan mempersiapkan generasi bangsa yang cakap dan terampil. Bahasa Inggris merupakan bahasa Internasional yang sangat penting untuk komunikasi dan menghubungkan masyarakat dengan dunia dalam berbagai aspek termasuk pendidikan. Pemerintah menunjukan keseriusan dalam meningkatkan kemampuan bahasa Inggris kepada genarasi bangsa yaitu dengan mewajibkan bahasa Inggris di jenjang pendidikan. Dalam kenyataannya, terdapat ragam kesulitan yang dihadapi oleh mahasiswa ketika belajar bahasa Inggris, terlebih pada pembelajar/ mahasiswa yang bukan dari jurusan bahasa Inggris yang disebut ESP (English for Specific Purposes) Learners. Penelitian ini bertujuan untuk menggali lebih dalam ragam kesulitan yang dihadapi oleh mahasiswa dalam belajar bahasa inggris pada mahasiswa Program Studi Pendidikan Bahasa Indonesia di FKIP Univesitas Ma'arif NU Kebumen. Penelitian ini menggunakan pendekatan kualitatif dengan instrumen kuesioner, observasi dan wawancara. Analisis data penelitian dilakukan melalui tiga tahap yaitu reduksi data, penyajian data dan penarikan kesimpulan. Hasil penelitian ini menunjukan bahwa subjek penelitian mengalami ragam kesulitan belajar bahasa Inggris yaitu: 1) kurangnya rasa percaya diri mahasiswa, 2) jarangnya mahasiswa praktik penggunaan bahasa Inggris dalam kehidupan sehari-hari dan, 3) kurangnya penguasaan kosa kata.
\end{abstract}

Kata kunci: ragam kesultan, pembelajaran, bahasa Inggris

Social, Humanities, and Education Studies (SHEs): Conference Series https://jurnal.uns.ac.id/shes

p-ISSN 2620-9284 e-ISSN 2620-9292 


\section{PENDAHULUAN}

Penguasaan bahasa Inggris sebagai bahasa internasional merupakan sebuah keniscayaan pada saat ini. Indonesia sebagai salah satu anggota MEA (Masyarakat Ekonomi ASEAN) sudah sepatutnya mempersiapkan tantangan ini dengan mempersiapkan generasi bangsa yang cakap dan terampil. Kemampuan dalam ilmu pengetahuan dan IPTEKS serta didukung dengan penguasaan bahasa asing sebagai bahasa komunikasi yang baik dan benar. Salah satu bahasa asing yang sangat penting adalah bahasa Inggris yang merupakan bahasa Internasional yang dapat menghubungkan masyarakat dengan dunia, dalam berbagai aspek, salah satunya adalah aspek pendidikan. Hal tersebut, diperkuat dengan kebijakan pemerintah terkait pendidikan yaitu dimana bahasa Inggris merupakan mata pelajaran wajib dari tingkat sekolah menengah sampai dengan tingkat atas SLTA (Sekolah Tingkat Atas). Bahkan, ditingkat pendidikan tinggi, seluruh program studi diwajibkan memberikan mata kuliah bahasa Inggris, sekalipun Prodi dengan disiplin ilmu pendidikan nonbahasa Inggris. Hal tersebut menunjukkan betapa pentingnya penguasaan bahasa asing, khususnya bahasa Inggris sebagai salah satu pengantar kesuksesan bidang akademik seseorang ataupun untuk menunjang karir dunia kerja (Sinaga, 2010).

Ada 4 (empat) hal yang seharusnya dikuasai oleh seseorang untuk berkomunikasi yaitu :menyimak, berbicara, menulis dan membaca. Istilah keempat tersebut dalam bahsa Inggris disebut English Competence Skill (listening and reading) sebagai receptive skill sedangkan reading dan speaking sebagai productive skill. Beberapa orang beranggapan bahwa dengan menguasai speaking maka menguasai semua skill, namun hal demikian tidak seutuhnya benar. Karena kemampuan/skill antara yang satu dengan yang lain saling terkait. Selain keempat skill trsebut diatas, masih ada terdapat 3 (tiga) elemen bahasa yang juga berperan penting dalam komunikasi yaitu pronunciation (pelafalan), vocabulary (kosa kata) dan grammar (struktur bahasa).

Untuk mewujudkan kemampuan bahasa Inggris yang maksimal, diperlukan pendidik/instruktur yang profesional sehingga menghasilkan peserta didik yang berkualitas. Selanjutnya harus ada keseimbangan antara pembelajaran teori dan pembelajaran praktik. Memang dalam kenyataannya bahwa untuk mewujudkan peserta didik dengan kemampuan yang profesional dan ideal tidaklah mudah. Selain pendidik harus menuasai materi yang cukup, mereka juga harus mengetahui tingkat kemampuan masing-masing peserta didiknya dengan baik. Sehingga pendidik tidak boleh menyamaratakan kondisi dalam proses pengajaran dan pembelajaran. Pada dasarnya setiap peserta didik memiliki karakteristik yang berbeda, termasuk pada teknik dan daya tangkap terhadap materi pembelajaran seperti pada konsep multiple intelligence (Stanford, 2003).

Dalam sebuah proses belajar mengajar mata pelajaran bahasa Inggris, sudah barang tentu bahwa setiap siswa mengalami sebuah hambatan dan kesulitan. Dimana kendala tersebut menjadikan hasil belajar yang kurang maksimal. Hal tersebut dapat terjadi oleh siapapun termasuk pada mahasiswa yang mengambil jurusan bahasa Inggris ataupun non bahasa Inggris. Kesulitan yang dihadapi oleh banyak pembelajar bahasa Inggris sebagai bahasa asing adalah ketidakfahaman pada pengucapan bahasa yang dilafalkan dengan kecepatan normal melalui materi listening (Hasan, 2000). Pada reading skill, masalah yang dihadapi untuk pemahaman teks bacaan terletak pada kurangnyapengetahuan tentang bahan bacaan dan ketidaktahuan bagaimana cara menghubungkan ide antara kalimat yang satu dengan kalimat yang lainnya. Selanjutnya keterampilan menulis merupakan hal rumit karena kegiatan tersebut membutuhkan proses pemikiran yang kompleks dan terstruktur, namun begitu keterampilan menulis/writing skill juga sangat perlu dikuasai oleh pembelajar bahasa Inggris. Dalam komunikasi keterampilan menulis juga penting untuk dikuasasi (Rukmini, 2011). Manfaat dari keterampilan ini akan sangat dirasakan dalam proses 
publikasi artikel ilmiah yang nantinya akan dibaca oleh khalayak umum.

Untuk keterampilan selanjutnya, adalah berbicara (speaking skill). Dalam sebuah penelitian, ditemukan bahwa kesulitanyang sering dijumpai oleh pembelajar bahasa Inggris adalah ketika mereka harus berbicara. Hal ini karena minimnya kosakata (vocabulary) dan juga pemahaman terhadap grammar dan structure (Megawati dan Madarani, 2016). Melihat beberapa permasalahan - permasalahan yang ada, seharusnya menjadi motivasi bagi setiap pendidik/dosen bahasa Inggris untuk lebih memperhatikan betul-betul kesiapan dalam pelaksanaan proses belajar mengajar. Dengan persiapan yang matang maka proses belajar mengajar diharapkan dapat menjadi efektif dan efisisen.

Persiapan dalam proses belajar mengajar dapat dilakukan dari kesiapan RPP (Rencana Pelaksanaan Pembelajaran) yang meliputi persiapan materi, media dan metode serta penilaian. Dengan memahami permasalahan yang dihadapi oleh mahasiswa, seorang pendidik/dosen nantinya dapat melakukan evaluasi dan refleksi diri untuk mengetahui sebarapa efektifitas dan efisiensi keterlaksanaan proses belajar mengajar dikelas, sehingga dapat digunakan sebagai bahan peningkatan kualitas proses pengajaran nantinya.

Permasalahan dalam proses belajar mengajar materi bahasa Inggris tidak hanya terjadi pada tingkat pendidikan dasar, menengah dan atas, namun juga terjadi pada tingkat perguruan tinggi. Ragam kesulitan mata kuliah bahasa Inggris tidak hanya dialami oleh mahasiswa yang ada pada jurusan bahasa Inggris, namun juga dari mahasiswa yang bukan berasal dari jurusan bahasa Inggris. Sehingga hal ini tidak dapat dipisahkan dari permasalhakan yang akan muncul pada saat proses belajar mengajar yang berlangsung nantinya. Pada kenyataanya bahwa pada setiap jurusan /Prorgram Studi mewajibkan bahasa Inggris menjadi salah satu matakuliah yang harus diampu. Bahkan pada di beberapa perguruan tinggi sudah memberlakukan suatu program yaitu menjelang semester akhir nantinya para mahasiswa diwajibkan lulus tes TOEFL dengan standar minimal yang ditentukan. Hal ini menjadi masalah yang sulit bagi para mahasiswa, terlebih bagi mereka yang tidak memiliki latar belakang pengetahuan bahasa yang kuat dari sejak SD sampai SLTA, pastinya mereka akan mengalami kesulitan.

Berdasarkan penjelasan yang telah dipaparkan pada pendahuluan ini, dapat dilihat bahwa banyaknya ragam kesulitan yang dihadapi oleh mahasiswa/pembelajar bahasa Inggris. Oleh karena itu peneliti tertarik untuk menggali lebih dalam ragam kesulitan yang dialami oleh para mahasiswa khususnya pada empat keterampilan bahasa. Hasil penelitian nantinya diharapkan dapata bermanfaat bagi yang berkepentingan sebagai informasi yang digunakan untuk bahan refleksi dan evaluasi. Hal inilah yang menjadi fokus peneliti bahwa para mahasiswa / pembelajar bahasa Inggris yang bukan dari jurusan bahasa Inggris, yaitu Program Studi Pendidikan Bahasa Indonesia FKIP UMNU Kebumen yang disebut sebagai ESP learners (English for Specific Purpose) berpotensi untuk menghasilkan ragam respon dalam proses perkuliahan.

\section{METODE}

Penelitian ini bertujuan untuk menggali lebih dalam tentang ragam kesulitan mahasiswa Prodi Pendidikan Bahasa Indonesia dalam belajar Bahasa Inggris. Sedangkan jenis penelitian ini merupakan penelitian kualitatif yang nantinya hasil dari penelitian ini berupa kata-kata atau kalimat yang merupakan hasil dari pengamatan. Penelitian dilaksanakan pada mahasiswa Program Studi Pendidikan Bahasa Indonesia T.A 2018-2019. Subjek penelitian adalah mahasiswa Universitas Ma'arif NU Kebumen yang mengambil mata kuliah Bahasa Inggris.

Data penelitian nantinya akan diperoleh dari metode yang akan dilaksanakan oleh peneliti yaitu metode penyebaran kuesioner, observasi dan juga wawancara (in 
deoth interview). Kuesioner akan diberikan kepada subjek peneltian untuk mengetahui respon mahasiswa tentang kesulitan belajar pada mata kuliah bahasa Inggris. Begitu juga data melalui pengamatan (observasi). Setelah itu, dilanjutkan dengan metode wawancara, dalam proses ini peneliti akan benar-benar menggali lebih dalam ragam kesulitan para mahasiswa dalam mengikuti proses pekuliahan bahasa Inggris. Sehingga setelah proses wawancara ini, peneliti dapat melakukan analisis dan menarik kesimpulan yang menunjukkan ragam kesulitan belajar mahasiswa Prodi Pendidikan Bahasa Indonesia pada mata kuliah bahasa Inggris di Universitas Ma'arif NU Kebumen.

Teknik triangulasi ini digunakan oleh peneliti untuk memeriksa kevalidan data pada penelitian. Sebagaimana disampaikan oleh (Sugiyono, 2006) bahwa ketika seorang peneliti melaksanakan triangulasi maka peneliti tersebut mengumpulkan data sekaligus mengecek apakah data yang diperoleh itu kredibel atau tida, dengan beragam teknik pengumulan data dan sumber referensi.

Pada penelitian ini, peneliti menganalisis data yang diperoleh dengan tiga langkah sebagai berikut:

1. Reduksi Data. Merangkum proses pengambilan data terkait hal-hal penting yang menjadi fokus peneliti.

2. Penyajian Data. Penyajian hasil data penelitian yang telah dirangkum dengan mendiskripsikan data secara merinci.

3. Penarikan Kesimpulan. Kesimpulan akan dipaparkan pertama kali bersifat sementara. Hal ini dikarenakan dapat berubah ketika adanya pendukung/referensi yang lebih kuat untuk validasi hasil pengumpulan data.

\section{HASIL DAN PEMBAHASAN}

Dari hasil yang diperoleh dari kuesioner, observasi dan diperkuat dengan wawancara, munculah ragam respon kesuliatan belajar mata kuliah bahasa Inggris pada mahasiswa Pendidikan Bahasa Indonesia di FKIP UMNU Kebumen. Sebelum masuk pada kemampuan intelektual (cognitive) dan keterampilan (skill) mahasiswa, peneliti menemukan masalah pada kemampuan mental mahasiswa, dalam hal ini yaitu rasa percaya diri (self confidence) yang hampir semuanya ada pada setiap mahasiswa. Masalah mental seperti, takut salah, malu jika ditertawakan oleh teman yang lain dan merasa kurangnya pemahaman terhadap konsep English grammar. Masalah tersebut dapat digolongkan sebagai masalah mental/ sikap (affective) mahasiswa yang muncul dari kebiasaan sehingga membentuk sebuah mental dan karakter siswa. Sehingga kurangnya rasa percaya diri ini menjadi masalah utama yang ditemukan oleh peneliti dalam penelitian ini.

Selanjutnya dalam hal praktik/membiasakan diri dalam menggunakan s juga ternyata menjadi salah satu faktor penyebab sebagian besar mahasiswa sulit dalam memahami mata kuliah bahasa Inggris. Padahal praktik dengan membiasakan penggunaan bahasa Inggris ini dalam kehidupan sehari-hari sangatlah membantu pemahaman mahasiswa sebagai pembelajar. Kemudian salah satu solusi dalam pembiasaan/praktik penggunaan bahasa Inggris adalah didunia akademik seperti ketika mahasiswa saling menyapa, berkenalan, menanyakan kabar dan juga ketika melakukan presentasi tugas/makalah pada setiap pembukaan (opening), bahasa pengantar ketika menyakan respon atau tanya jawab dan juga ketika penutupan (closing) menggunakan bahasa Inggris.

Kemudian diperkuat dalam pelatihan Public Speaking (Berbicara ditempat Umum) seperti menjadi MC (Master of Ceremony), News Anker (Pembawa Berita), Speech (Pidato), Debat (Debate), Story Telling (Bercerita) dan lain-lain. Selanjutnya pelatihan tersebut dikemas oleh peneliti dalam sebuah modul yang dapat menjadi sebuah model-model pengajaran bagi dosen dan pembelajaran oleh para mahasiswa secara umum terutama mahasiswa Prodi Pendidikan Bahasa Indonesia. 
Permasalahan kurangnya praktik penggunaan bahasa Inggris ini senada dengan penelitian (Afisa dan Yolanda, 2015) yaitu mereka menyatakan bahwa faktor penyebab kesulitan dalam belajar berbicara bahasa Inggris adalah jumlah frkuensi praktik berbicara bahasa Inggris dan faktor psikologi.

Kemampuan dalam berbahasa Inggris dapat digolongkan sebagai kemampuan intelektual sekaligus keterampilan. Seperti kemampuan berbicara (speaking), mendengarkan (listening), membaca (reading) dan menuis (writing). Samua kemampuan/keterampilan tersebut menuntut mahasiswa untuk berfikir dan berkreasi. Selanjutnya masuk pada kemampuan intelektual dan keterampilan (skill) mahasiswa. Kemampuan berbicara (speaking) merupakan kesulitan yang paling banyak dialami oleh mahasiswa. Dalam berbicara ini memang sangat menuntuk kemampuan mahasiswa dalam menghafal kosakata, menyusun setiap kata menjadi kalimat yang sesuai dengan grammar dan juga pengucapan yang harus sesuai dengan kaidah pengucapan kata bahasa Inggris (pronunciation). Tingkat kesulitan English Skill yang nomor dua yaitu listening. Sebagian mahasiswa mengalami kesulitan pada keterampilan ini, terlebih jika penutur asli (native speaker) yang menjadi pengucap dalam sebuah rekaman suara / vidio. Kurangnya penguasaaan kosa kata dan pengucapan aksen dan kecepatan dalam pengucapan juga yang sering kali menjadikan mereka tidak dapat mengerti apa yang sedang dibicarakan. (Paaki, 2003) yang meneliti tentang pembelajar bahasa Inggris antara orang Jepang dan Finlandia. Disebutkan bahwa kondisi pembelajar bahasa Inggris dari Jepang dipengaruhi oleh perbedaan aksen, sehingga pemahaman pada proses menyimak tidak maksimal, hal ini membawa dampak pada pengucapan bahasa target. Sedangkan pembelajar dari Finlandia merasa bahwa aksen British sangat melekat pada mereka sehingga bahasa yang dihasilkanpun tergolong baik.

Selanjunya adalah kemampuan menulis (writing) merupakan keterampilan yang kompleks berikunya bagi pembelajar ESP (English for Specific Purposes). Dalam keterampilan memiliki poin kesulitan yang sama dengan speaking yaitu dimana mahsiswa dituntut penguasaan kosa kata sesuai dengan konteks dan merangkainya sesuai kaidah penulisan bahasa Inggris. Selanjutnya keterampilan dengan kesulitan terendah secara umum yang dihadapi oleh mahasiswa adalah membaca (reading). Seanjutnya, hasil analisis data penelitian dan wawancara semua pengajar bahasa agar memperhatikan tingkat kesulitan pada pemilihan konteks bacaan bahasa Inggris dengan kompetensi dan kebutuhan mahasiswa (Johnson, 1930).

Dari hasil dan pembahasa diatas, menunjukan bahwa mayoritas mahasiswa rendah dalam kemampuan penguasaan kosa kata (vocabulary). Sehingga peniliti menyimpulkan bahwa salah satu dari ragam kesulitan mahasiswa Prodi Pendidikan Bahasa Indonesia dalam belajar mata kuliah bahasa Inggris adalah kurangnya penguasaan kosa kata bahasa Inggris.

\section{SIMPULAN}

Proses pembelajaran mata kuliah bahasa Inggris tidak dapat dipisahkan dengan munculnya ragam kesulitan para pembelajarnya, dlam konteks penelitia ini yaitu mahasiswa Prodi Pendidikan Bahasa Indonesia yang notabenenya mereka sebagai pembelajar ESP. hasil penelitian menunjukkan bahwa sebagian besar mahasiswa mengalami ragam kesulitan diantaranya sebagai berikut: (1) Rasa kurangnya percaya diri untuk tampil; (2) Kurangnya praktik penggunaan bahsa Inggris dalam kehidupan sehariOhari untuk berkomunikasi; (3) Kurangnya penguasaan kosa kata yang dimiliki oleh mahasiswa.

Mendasar pada penelitian ini, dapat dikemukakan sebuah implikasi. Pemilihan metode pengajaran yang tepat dapat mempengaruhi terhadap ragam kesulitan mahasiswa dalam mengikuti ata kuliah bahasa Inggris. Selanjutnya faktor kebiasaan, personal dan lingkungan. Hasil penelitian ini diharapkan dapat diginakan oleh para 
dosen untuk membenahi diri terkait dengan metode pengajaran mata kuliah bahasa Inggris kepada pembelajar non bahasa Inggris (ESP learners). Selanjutnya para dosen juga harus dapat menginventarisasi ragam kesulitan mahasiswa, sehingga dalam mengajar selalu mengacu pada latar belakang tingkat kemampuan dan kebutuhan mahasiswa.

Selama dalam pelaksanaan penelitian ini, peneliti memperoleh temuan-temuan yang dapat dijadikan sebagai acuan untuk merekomendasikan hal-hal sebagai berikut;

1. Dalam setiap perkuliahan, dosen diharapkan mengawali dengan memberikan motivasi, sehingga mahasiswa dapat tumbuh rasa percaya diri dengan tidak merasa takut melakukan kesalahan dalam proses pembelajaran;

2. Dalam rangka peningkatan kemampuan kosa kata mahasiswa, sebaiknya para dosen/pengajar bahasa Inggris dapat mengaitkan materi dengan kebutuhan mahasiswa, mengingat mahasiswa/pembelajar ini bukanlah dari jurusan bahasa Inggris.

3. Proses belajar pada matakuliah bahasa Ingris harus dibuat yang memaksakan mahasiswa untuk terlibat/praktik langsung. Memperbanyak keterlibatan mahasiswa ini dengan pendekatan SCL (Students Centered Learning).

4. Sebelum proses pembelajaran dilaksanakan, sebaiknya direncanakan dengan cermat terlebih dahulu, melalui RPP (Rencana Pelaksanaan Pembelajaran) dengan menyesuaikanantara materi, media dan metode.

\section{DAFTAR PUSTAKA}

Afisa, P., dan Yolanda, S (2015). The Students' Difficulties In Speaking At The Tenth Grade Of SMA Negeri 1 Sine 2014/2015 Academic Year (Doctoral dissertation, Ma'arif NU University of surakarta).

Hasan, A.S. (2000). Learners' perceptions of Listening Comprehension problems. Language Culture and Curriculum, 13(2), 137-153.

Johnson, G.R (1930). An Objective Methode of determining Reading Difficulty. The Journal of Educational Research, 21(4), 283-287.

Paaki, H. (2013). Difficulties in Speaking English and Perceptions of Accents: A Comparative Study of Finish and Japanese Adult Learners of English. Unpubished Master's Thesis, University of Eastern Finland.

Rukmini, A.S. (2011). The Implementation of Teacher Corrective Feedback in Teaching Writing Descriptive Text to The Second Year Students of SMPN 1 Tunjungan in 2010/2011 Academic Year (Doctoral dissertation, University Ma'arif NU Surakarta).

Sugiyono, M.P.P.P.K. (2006). Kualitatif dan $R$ and D. Bandung: Alfabeta.

Standford, P. (2003). Multiple Intelligence For Every Classroom. Intervention In School and Clinic, 39(2), 80-85. Peranan Bahasa Inggris. 